\title{
Correction to: Ibn Khaldūn and the Arab Origins of the Sociology of Civilization and Power
}

\section{Correction to:}

\author{
A. Verza, Ibn Khaldūn and the Arab Origins of the Sociology \\ of Civilisation and Power, \\ https://doi.org/10.1007/978-3-030-70339-4
}

The book was inadvertently published with typographical errors in names with special characters. These typographical errors have now been corrected along with certain grammatical errors throughout the book. The names have been corrected in the reference list across all the chapters in the book. 